\title{
Retinalis biomarkerek szerepe a vascularis dementia és az Alzheimer-kór korai formáinak diagnosztikájában
}

\author{
Élő Ágnes - Czakó Cecília dr. - István Lilla dr. - Benyó Fruzsina dr. \\ Nagy Zoltán Zsolt dr. - Kovács Illés dr.
}

Semmelweis Egyetem, Általános Orvostudományi Kar, Szemészeti Klinika, Budapest

\begin{abstract}
A dementiák társadalmunkban egyre nagyobb problémát jelentenek, folyamatosan nő a megbetegedések száma. A dementia leggyakoribb előfordulási formája az Alzheimer-kór, mely az esetek 60-80\%-áért felelős. Kórlefolyása hosszú, a preklinikai stádiumtól a súlyos Alzheimer-kórig több év, évtized is eltelik. Az Alzheimer-kór egy olyan progresszív neurodegeneratív betegség, amely súlyos szellemi leépüléshez vezet. A diagnózishoz számos, kognitív funkciót mérő teszt és képalkotó vizsgálat áll rendelkezésre, a korai diagnózis azonban nagyobb kihívást jelent, így a betegség gyakran későn kerül felismerésre. Mivel az agyi és a retinalis keringés között bizonyítottan kapcsolat van, felmerül annak lehetôsége, hogy a retina vizsgálata az Alzheimer-kór és a vascularis dementiák korai diagnózisában és progressziójának követéséhez is segítséget nyújthat. Az utóbbi években a retina képalkotó vizsgálataiban bekövetkezett fejlődésnek köszönhetően lehetővé vált a retina strukturális és vérkeringési elváltozásainak vizsgálata a dementiák különböző típusaiban. Ezek alkalmazása nemcsak a korai diagnózisban, hanem a progresszió megítélésében és a terápia nyomon követésében is segítséget nyújthat a jövőben. Orv Hetil. 2020; 161(41): 1744-1752.
\end{abstract}

Kulcsszavak: vascularis dementia, Alzheimer-kór, retina-képalkotás

\section{Retinal biomarkers for early diagnosis of vascular dementia and Alzheimer's disease}

Dementia is an emerging problem in our society, and the number of diseases is constantly increasing. The most common cause of vascular dementia is Alzheimer's disease, which is responsible for $60-80 \%$ of the cases. The progress of Alzheimer's disease is slow, it usually takes years or decades from the preclinical stage to the last stage. Alzheimer's disease is a progressive neurodegenerative disease that leads to severe mental decline. Several mental and imaging tests are available to help the diagnosis, but early detection of the disease is usually more challenging, often leading to late recognition. As the cerebral and retinal circulation have similarities, retinal imaging can help in the early diagnosis and progression analysis of Alzheimer's disease and vascular dementia. Recent advances in retinal imaging have made it possible to study early structural and circulatory changes in the retina of patients with dementia. Their future application might help not only in the early diagnosis but also in the assessment of progression.

Keywords: vascular dementia, Alzheimer's disease, retinal imaging

Élő Á, Czakó C, István L, Benyó F, Nagy ZZs, Kovács I. [Retinal biomarkers for early diagnosis of vascular dementia and Alzheimer's disease]. Orv Hetil. 2020; 161(41): 1744-1752.

(Beérkezett: 2020. április 8.; elfogadva: 2020. május 2.) 


\section{Rövidítések}

ADAS $=($ Alzheimer's Disease Assessment Scale $)$ az Alzheimerbetegség értékelési skálája; ADAS-Cog $=($ Alzheimer's Disease Assessment Scale, Cognitive Subscale) az Alzheimer-kór értékelési skálájának kognitív alskálája; $\mathrm{CDR}=($ Clinical Dementia Rating) a klinikai dementia besorolása; $\mathrm{CT}=($ computed tomography) számítógépes tomográfia; DSM-IV-TR = Diagnostic and Statistical Manual of Mental Disorders, 4th Edition, Text Revision; DVA = (dynamic vessel analyzer $)$ dinamikus éranalizátor; $\mathrm{FAZ}$ = fovealis avascularis zóna; $\mathrm{FD}=$ fraktáldimenzió; FLAG = (fluorescein angiography) fluoreszcens angiográfia; GCC = (ganglion cell complex) ganglionsejt-komplexum; MCI $=$ (mild cognitive impairment) enyhe kognitív zavar; MMSE $=($ Mini Mental State Examination $)$ Mini Mentális Teszt; MoCA $=($ Montreal Cognitive Assessment $)$ Montreali Kognitív Felmérés; MRI = (magnetic resonance imaging $)$ mágnesesrezonancia-képalkotás; OCT = (optical coherence tomography) optikaikoherencia-tomográfia; OCTA = (optical coherence tomography angiography) optikaikoherencia-tomográfiás angiográfia; PET = (positron emission tomography) pozitronemissziós tomográfia

\section{Az Alzheimer-kór}

A társadalom növekvő átlagéletkorával egyre fokozódik az Alzheimer-kór előfordulása is, amely a dementia eseteinek 60-80\%-áért felelős [1]. A betegség névadója Alois Alzheimer német neurológus, aki elsőként írta le a kórt, 1907-ben [2]. Akkoriban még nem fogadták el széles körben az elméletét, miszerint nem egy normális, öregedéssel járó folyamatról van szó, hanem olyan betegségről, mely az agykéreg kóros elváltozásaival jár. Ma azonban már jól ismertek a betegség jellegzetes patológiai és szövettani eltérései. A neuronokban neurofibrillaris kötegek jelennek meg, melyek tulajdonképpen kötegekbe rendeződött hiperfoszforilált fehérjék (tau-fehérjék), a sejteken kívül pedig béta-amyloid plakkok mutathatók ki, továbbá vascularis patológia is szerepet játszik a neurodegeneratív folyamatokon kívül a kialakulásban [3].

Az Alzeimer-kór lefolyása hosszú, melynek során nemcsak a kognitív funkciók romlanak, hanem egyéb, nem kognitív tünetek is jelentkeznek, mint szorongás, depresszió, téveszmék, személyiségváltozás. Jellemzően három stádiumot különítenek el, melyek az enyhe, a mérsékelt és a súlyos Alzheimer-kór, bár ezek gyakran nem választhatók szét élesen [4]. A progresszió a már diagnosztizált betegek esetében nehezen jósolható meg, ismert ugyanis, hogy a kognitív funkciók nagyon eltérő ütemben romlanak a betegekben: körülbelül egyharmadukban semmilyen változás nem tapasztalható öt év alatt, míg egyharmadukban mérsékelt sebességü, egyharmadukban pedig nagyon gyors a kognitív hanyatlás. A halál gyakran valamely külső tényező miatt következik be, úgymint húgyúti infekció, tüdőgyulladás vagy felfekvés okozta szepszis.

Míg 2017-ben az Alzheimer-kór a világon 44 millió embert érintett, becslések szerint 2050-re ez az érték több mint a háromszorosára fog nőni, jelentős terhet róva a fejlett társadalmakra [5].

\section{Az Alzheimer-kór preklinikai formája}

Az amyloidkaszkád-hipotézis szerint az Alzheimer-kór klinikai tüneteinek megjelenése előtt már évekkel vagy akár évtizedekkel kialakulnak a patológiai elváltozások, ezt az állapotot nevezzük preklinikai stádiumnak [6]. A preklinikai stádiumot még további szakaszokra lehet osztani a patológiai elváltozások alapján [7]; a három szakaszból az utolsónál kezdi észlelni a beteg is a tüneteket, ennek ellenére a dementiateszteken még jól teljesít. A klinikai tünetekkel való formába történő progresszióban a béta-amyloid felhalmozódása a kulcslépés, ha ugyanis ez jelen van, és genetikailag is hajlamos rá az egyén, nagy a valószínúsége az Alzheimer-kór kialakulásának [8].

\section{Az enyhe kognitív zavar (mild cognitive impairment)}

Az enyhe kognitív zavar (MCI) egy olyan, nehezen definiálható szindróma, melyre jellemző, hogy az érintett egyén kognitív hanyatlása nagyobb, mint amit korának és iskolai végzettségének megfelelően elvárnának, de az a mindennapi tevékenységét nem befolyásolja. Az esetek egy része nem progrediál, míg az esetek felében 5 éven belül dementia alakul ki [9]. Az MCI fogalmát Petersen és mtsai vezették be először a szakirodalomba [10], és az emlékezetzavar alapján két fó formáját különböztették meg, az ún. amnesztikus típust, amelynél az emlékezetzavar a fó tünet, valamint a nonamnesztikus MCI-t, amelynél az egyéb tünetek vannak túlsúlyban.

Ezt a meghatározást fejlesztette tovább Rosenberg, Johnston és Lyketsos [11], miszerint memóriazavar megléte esetén fel kell mérni, hogy megfelelő-e a személy kogníciója, illetve megőrzöttek-e a mindennapi életvitelhez szükséges mentális funkciói. A DSM-IV-TR alapján a diagnózis megállapításához a következókből két tünetnek legalább 2 hétig történő fennállása szükséges: memóriazavar felidézéskor vagy tanuláskor, a végrehajtó funkciók zavara (cselekvés tervezésének, végrehajtásának vagy a döntéshozásnak a nehézsége), a figyelem vagy az információfeldolgozás sebességének zavara, a nyelvi kifejezés deficitje [12].

Sajnálatos módon az MCI gyakran progrediál: az amnesztikus típus általában Alzheimer-kórba és vascularis dementiába megy át, a nonamnesztikus típus pedig jellemzően vagy frontotemporalis dementia, vagy Lewytestes dementia lesz a későbbiekben [13].

\section{A jelenleg alkalmazott diagnosztikai módszerek}

\section{Kognitín funkciókat méró tesztek}

A dementiák korai formáinak diagnózisa nem egyszerű feladat, sokszor csak a későbbi stádiumokban állítható fel egyértelmúen a diagnózis. Az első lépés a dementiagya- 
1. táblázat |A vascularis dementiák diagnosztikájában használt kérdőíves vizsgálatok szenzitivitása és specificitása Alzheimer-kórban

\begin{tabular}{lccc}
\hline Teszt & Szenzitivitás (\%) & Specificitás (\%) & Forrás \\
\hline MoCA & 80 & 81 & {$[19]$} \\
MMSE & 66 & 73 & {$[19]$} \\
ADAS-Cog & 84 & 91 & {$[17]$} \\
CDR & 45 & 85 & {$[18]$} \\
\hline
\end{tabular}

ADAS-Cog = az Alzheimer-kór értékelési skálájának kognitív alskálája; $\mathrm{CDR}=$ a klinikai dementia besorolása MMSE = Mini Mentális Teszt; $\mathrm{MoCa}=$ Montreali Kognitív Felmérés

nús betegeknél a részletes anamnézisfelvétel, a beteg környezetében élők kikérdezése, ugyanis maguk a betegek gyakran nincsenek tudatában szellemi hanyatlásuknak. Ezt követi a kognitív funkciókat mérő tesztek alkalmazása, melyekkel az Alzheimer-kór okozta szellemi hanyatlás jól mérhető. Napjainkban a legszélesebb körben használt ilyen teszt az ún. Mini Mentális Teszt (MMSE - Mini Mental State Examination), mely két részből áll. Az első részben a vizsgálati személy szóban válaszol kérdésekre, ezek lehetnek orientációs, mondatismétléses, megnevezéses, illetve különböző végrehajtó funkciókat vizsgáló kérdések. A második részben szereplő feladatokkal fóleg az írási és rajzolási készségek mérhetők [14].

Az Alzheimer-kór progressziójának nyomon követésére alkalmas az Alzheimer's Disease Assessment Scale (ADAS-) teszt is, mely egy kognitív (ADAS-Cog) és egy nem kognitív részre különül el [15]. Az ADAS-Cog képes elkülöníteni az enyhe kognitív zavart mind a normális öregedés állapotától, mind az Alzheimer-kórtól [16, 17].

Egy másik, klinikumorientált pontrendszer, a Clinical Dementia Rating (CDR) hat különböző, kognitív és magatartásbeli tényezőt vizsgál, mint a memória, az orientáció, a megítélés és problémamegoldás, a közösségi tényezők, az otthoni tevékenységek és hobbik, valamint a személyes gondolkodás aspektusait. A teszt eredményeit egy 0-tól 3-ig terjedő skálán adhatjuk meg: nincs dementia $(\mathrm{CDR}=0)$, megkérdőjelezhető a dementia
$(\mathrm{CDR}=0,5), \mathrm{MCI}(\mathrm{CDR}=1)$, közepes kognitív károsodás $(\mathrm{CDR}=2)$ és súlyos kognitív károsodás $(\mathrm{CDR}=3)$ [18].

Az Alzheimer-kór kimutatásánál nagyobb nehézséget jelent az MCI, illetve a preklinikai formák felismerése, ezekben az állapotokban ugyanis az MMSE jellemzően nem mutat eltérést. Az MCI esetében hatásosnak bizonyult a MoCA-teszt, mely hasonlít az MMSE-hez, de több funkciót vizsgál, és a pontozás is eltérő [19, 20]. A vascularis dementiák diagnosztikájában használatos legelterjedtebb kérdőívek diagnosztikai érzékenysége Alzheimer-kór esetében elfogadható, de a korai formákban szenzitivitásuk és specificitásuk jellemzően alacsonyabb (1. táblázat) [17-19].

\section{Képalkotó és liquorvizsgálatok}

Az anamnézis és a kognitív tesztek után további vizsgálati módszerek is szóba jönnek. A kiterjesztett diagnosztika része a képalkotó vizsgálatok elvégzése (MRI, PET), a liquor elemzése és a vérből történő laborvizsgálatok. Noha a liquor biomarkerei közül a béta-amyloid, a teljes tau és a foszforilált tau szintje már a preklinikai formákban is emelkedett lehet, a vizsgálat az invazív jellege miatt nem vált a rutindiagnosztika részévé. Az MRI-felvételen látható jellegzetes eltérések - mint az agykéreg elvékonyodása, a hippocampusatrophia, illetve a sulcusok kitágulása - elsősorban az előrehaladott formákban jelennek meg, így az MCI és a preklinikai formák kimutatására nem használhatók. PET-vizsgálattal az extracellularisan lerakódott béta-amyloid és az intracellularisan összegyúlt tau-proteinek jól detektálhatók ugyan, a vizsgálathoz azonban jelölőanyag alkalmazása szükséges, melynek ára gátolja a módszer klinikai gyakorlatban való elterjedését. A két biomarker közül a tau-proteinek jelenléte bizonyult jobb kórjelzőnek, eloszlása jól korrelál a betegség előrehaladtával $[21,22]$. A betegség különböző stádiumaiban a képalkotó vizsgálatokkal látott jellegzetes eltéréseket a 2. táblázat foglalja össze.

Megjegyezzük, hogy míg a liquorvizsgálatok diagnosztikai érzékenysége a korai formák esetén is elfogadható, a PET-vizsgálat ilyen esetekben alacsony szenzitivi-

2. táblázat | Képalkotó vizsgálatok során látott jellegzetes eltérések az Alzheimer-kór különböző stádiumaiban

\begin{tabular}{llll}
\hline & Preklinikai Alzheimer-kór & MCI & Alzheimer-kór \\
\hline CT & Nincs jellegzetes elváltozás & Enyhe kamratágulat & $\begin{array}{l}\text { Temporalislebeny-atrophia, a temporalis } \\
\text { szarvak és a Sylvius-hasadékok megna- } \\
\text { gyobbodása }\end{array}$ \\
\hline MRI & $\begin{array}{l}\text { Nincs elváltozás, vagy enyhe } \\
\text { cerebralis atrophia látható }\end{array}$ & $\begin{array}{l}\text { A hippocampust is magában foglaló temporalis- } \\
\text { lebeny-atrophia + oldalkamra-tágulat }\end{array}$ & $\begin{array}{l}\text { Kifejezettebb atrophia és oldalkamra- } \\
\text { tágulat }\end{array}$ \\
\hline PET & $\begin{array}{l}\text { Alacsonyabb FDG-felvétel a } \\
\text { temporalis és a parietalis kéregben }\end{array}$ & $\begin{array}{l}\text { Kimutatható a béta-amyloid és a tau-fehérje } \\
\text { lerakódása bizonyos radioaktív izotópokkal jelölt } \\
\text { vegyületek segítségével; a lerakódás területein ezen } \\
\text { vegyületek fokozott felvétele látszik }\end{array}$ & $\begin{array}{l}\text { A vegyületek felvétele ugyanazon } \\
\text { területeken, mint a korai stádiumban, } \\
\text { de a felvétel mértéke alacsonyabb }\end{array}$ \\
\end{tabular}

CT = számítógépes tomográfia FDG = fluor-dezoxi-glükóz; MCI = enyhe kognitív zavar; MRI = mágnesesrezonancia-képalkotás; PET = pozit ronemissziós tomográfia 
3. táblázat

A PET- és liquorvizsgálatok diagnosztikai pontossága az enyhe kognitív zavar és az Alzheimer-kór kimutatásában

\begin{tabular}{lcc|ccc}
\hline Vizsgálómódszer & \multicolumn{2}{c|}{ MCI } & \multicolumn{2}{c}{ Alzheimer-kór } & Forrás \\
\cline { 2 - 5 } & $\begin{array}{c}\text { Szenz. } \\
(\%)\end{array}$ & $\begin{array}{c}\text { Spec. } \\
(\%)\end{array}$ & $\begin{array}{c}\text { Szenz. } \\
(\%)\end{array}$ & $\begin{array}{c}\text { Spec. } \\
(\%)\end{array}$ & \\
\hline FDG-PET & & & & & \\
Tapasztalt értékelő által & 14 & 76 & 57 & 91 & {$[23]$} \\
$\begin{array}{l}\text { Mesterséges intelligencia } \\
\text { alkalmazásával }\end{array}$ & 43 & 58 & 100 & 82 & \\
\hline Liquor (teljes tau) & 84 & 63 & 87 & 84 & {$[24]$} \\
\hline
\end{tabular}

FDG = fluor-dezoxi-glükóz; MCI = enyhe kognitív zavar; PET = pozitronemissziós tomográfia

tású, mely azonban mesterséges intelligencia alkalmazásával jelentősen növelhető (3. táblázat) [23,24]. Ugyanakkor míg a korábban részletezett diagnosztikai módszerek az agyi morfológiai és funkcionális eltéréseket, illetve a liquor összetételének változásait jellemzik, újabban felmerült a retina képalkotó vizsgálatain alapuló diagnosztikai módszerek alkalmazása is. A retina és az agy fejlődéstani és strukturális hasonlósága révén ezek a módszerek noninvazív, gyors vizsgálattal szolgáltathatnak adatokat a retina szerkezeti és funkcionális állapotáról és ezáltal a dementiához társuló agyi neuralis kiserek változásairól.

\section{A retina strukturális eltérései Alzheimer- kórban}

Hinton és mtsai 1986-ban post mortem retinaminták hisztológiai vizsgálatait követően Alzheimer-kórban szenvedő betegek retinájában a ganglionsejt- és az idegrostréteg elvékonyodását írták le [25]. Későbbi szövetta- ni vizsgálatok aztán kimutatták a béta-amyloid-plakkok jelenlétét a fotoreceptor-rétegben, a ganglionsejt- és idegrostrétegben, illetve a külső és belső rostos rétegben a betegség korai stádiumában, még a neurológiai tünetek megjelenése előtt. Ezen plakkok hatása a retinalis sejtek és kapcsolatok múködésére még nem tisztázott, de bizonyítottan az astrocyták számának és az astrocyta/ idegsejt aránynak a növekedéséhez vezet. A retinában a tau-fehérje jelenlétét is kimutatták, amely elsősorban a ganglionsejtréteg dendritjeiben és intraretinalis axonokban halmozódik fel, ugyanakkor további vizsgálatok szükségesek a tau-proteinek felhalmozódása és az Alzheimer-kór okozta egyéb retinalis változások közötti öszszefüggések tisztázására.

Pásztázó lézeroftalmoszkóppal (scanning laser ophthalmoscope) vizsgálva in vivo kimutatható a retinában a béta-amyloid-plakkok jelenléte Alzheimer-kórban [26]. Továbbá ilyen esetekben a retina perifériás területein sárgásfehér subretinalis depozitumok (drusenek) felhalmozódása figyelhető meg, melyet egyéb vascularis változások kísérnek, mint például az erek fraktáldimenziójának (FD) csökkenése és a vénák tágulata [27]. Az FD a retinalis érhálózat elágazódási rendszerének komplexitását tükrözi: minél nagyobb az FD-hányados, annál részletgazdagabb az elágazódás. Az erek elágazódásának csökkenése lassú folyamat, és elsősorban a dementiák előrehaladottabb formáiban figyelhetó meg.

A szemfenéki fotón látható vascularis eltérésekkel szemben az optikaikoherencia-tomográfia (OCT) a retina in vivo keresztmetszeti leképezésére alkalmas módszer. A mindössze néhány másodperces, noninvazív vizsgálat nagy felbontású képeket szolgáltat a retináról, és a beépített automata szegmentációs algoritmusok révén lehetővé válik a maculában a retina rétegeinek vastagságmérése (1. ábra). Nem demens idős személyekkel össze-

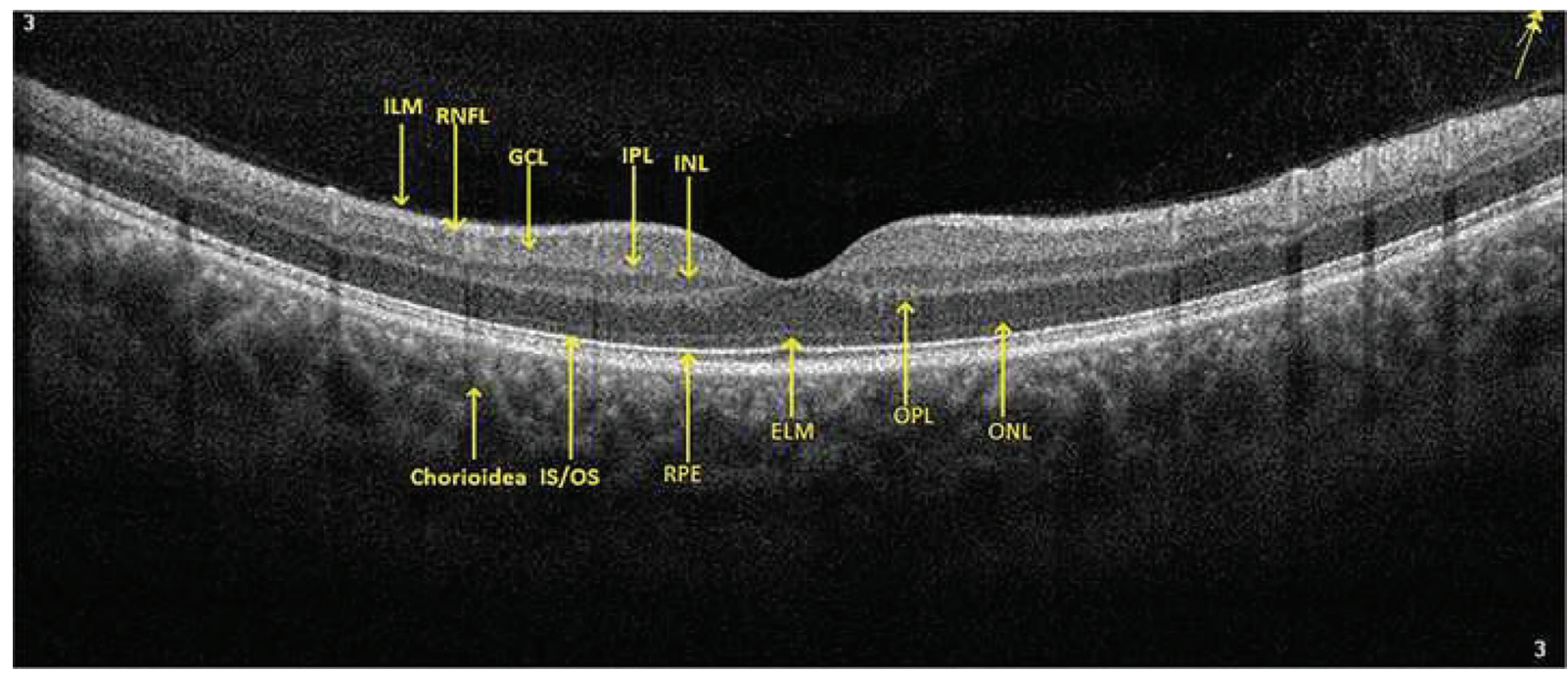

1. ábra
A retina rétegei optikaikoherencia-tomográfiás felvételen
$\mathrm{ELM}=$ membrana limitans externa; $\mathrm{GCL}=$ ganglionsejtréteg; $\mathrm{ILM}=$ membrana limitans interna; $\mathrm{INL}=$ belső nukleáris réteg; IPL $=$ belső plexiform réteg; IS/OS = fotoreceptor belső/külső szegmens átmenet; $\mathrm{ONL}=$ külső nukleáris réteg; $\mathrm{OPL}=$ külső plexiform réteg; RNFL = a retina idegrost- rétege; $\mathrm{RPE}=$ a retina pigmentepithelium-rétege 
A

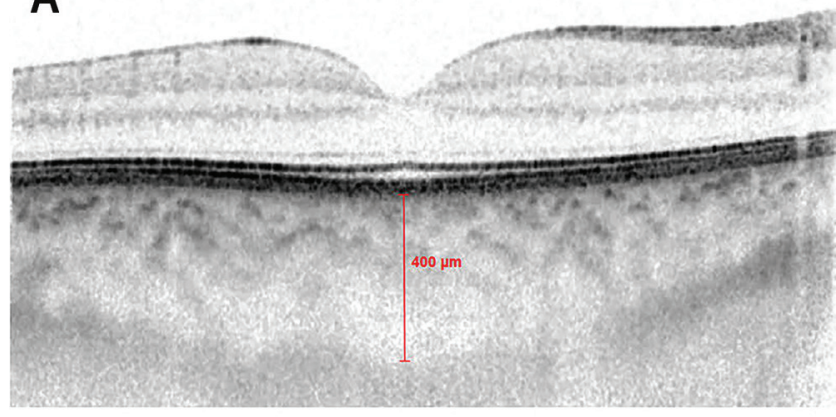

B

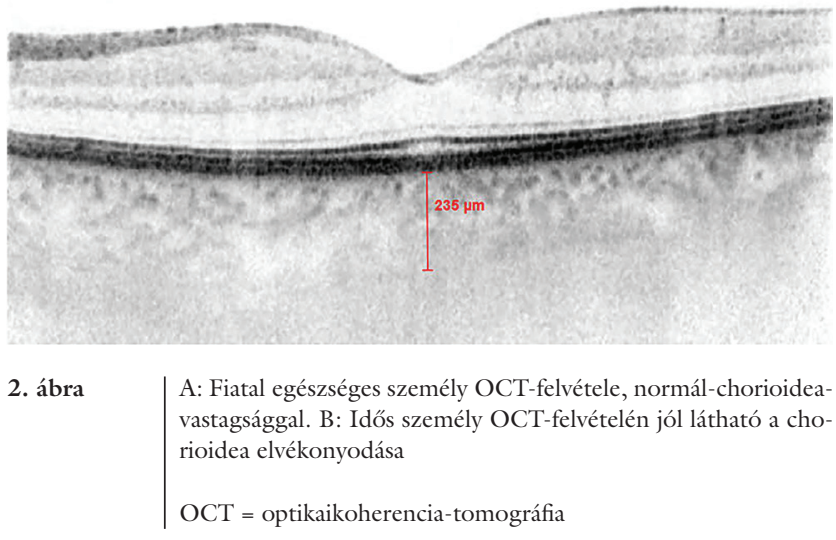

hasonlítva OCT-vizsgálattal Alzheimer-kóros betegekben a chorioidea elvékonyodása látható, mely folyamat feltételezhetően az agyi hypoperfusio és atrophia szemészeti megfelelője (2. ábra) [28]. A chorioidea atrophiáját a peripapillaris és macularis idegrost- és ganglionsejtréteg elvékonyodása és a macula térfogatcsökkenése kíséri, mely változások már az MCI-stádiumban is kimutathatók, az OCT-vizsgálatnak a korai diagnosztikában nyújtott szerepére utalva (3. ábra) [29].

\section{A retina keringési eltérései Alzheimer- kórban}

A retina vérellátását az arteria centralis retinae és ágai adják. A retina kapillárisai több rétegben helyezkednek el, így megkülönböztetünk felszíni, intermedier, mély, illetve peripapillaris kapillárisplexust. A fovea centralis 500 mikrométernyi területén nincsenek erek (fovealis avascularis zóna - FAZ), a perifovealis kapillárishálózat érhurkai elkerülik azt. Az egészséges érfal áttetsző, tükrözéskor a felszínes retinaerekben áramló véroszlopot látjuk [30].

A retina és annak erei neuroectodermalis eredetúek, így az erek a cerebralis erekkel azonos tulajdonságúak, amit alátámaszt a vér-agy gát és a vér-retina gát nagyfokú hasonlósága is [31, 32]. Jogosan feltételezhető tehát, hogy a retina ereinek vizsgálata hasznos lehet az Alzheimer-kór és az MCI diagnosztikájában, illetve a betegség
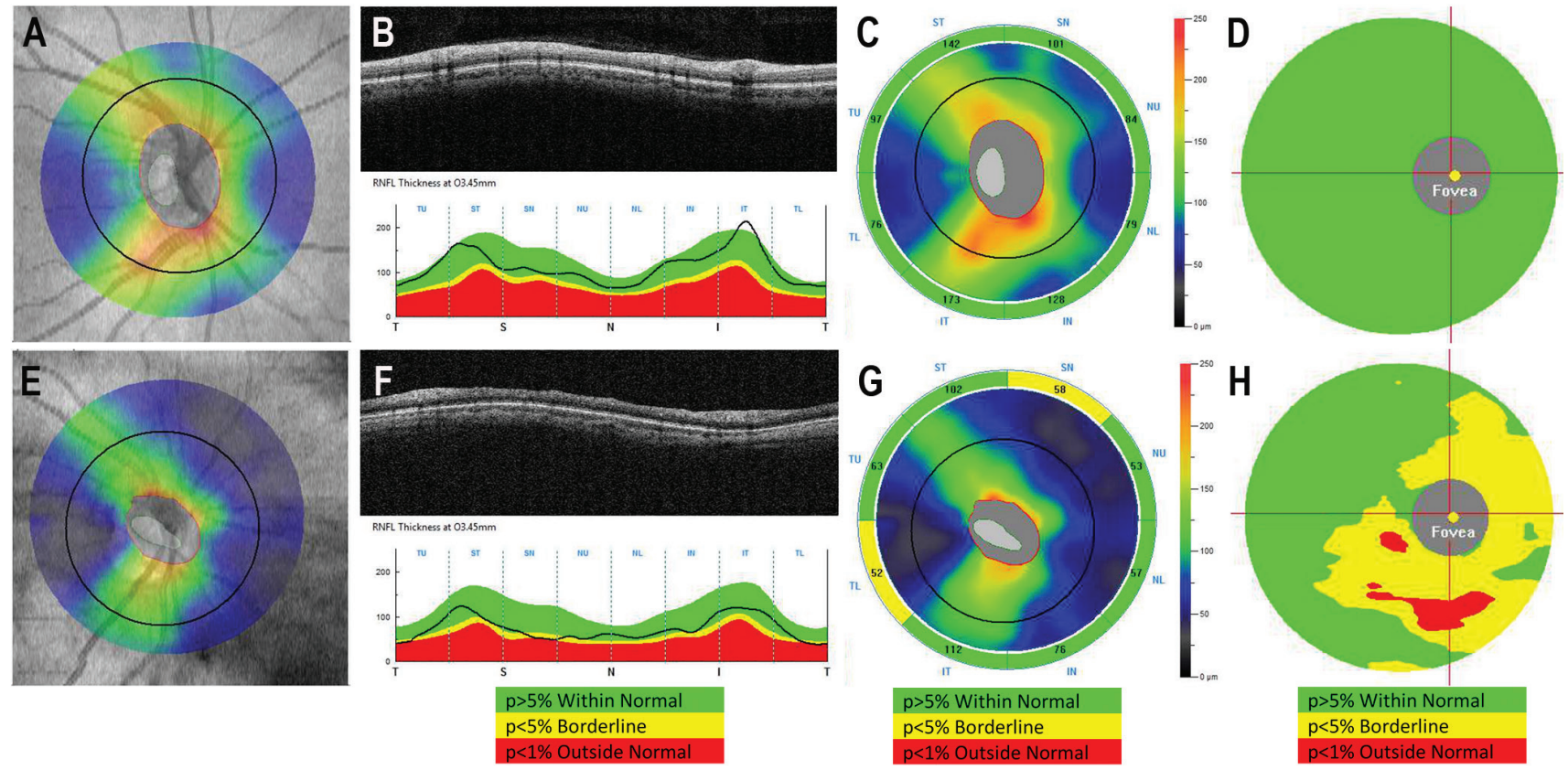

3. ábra

Az idegrostrétegről (RNFL) és a ganglionsejt-komplexumról (GCC) készült OCT-felvételek normál (A-D) és kóros (E-H) esetben. A papilla körüli körkörös leképezés során (A és E) a kóros esetben az RNFL vastagsága mindenhol jól láthatóan csökkent (B és F). A normáladatbázissal összehasonlítva a kóros esetben az RNFL egyes szegmentumokban határérték elvékonyodása látható (C és G). A maculában a GCC-határérték, illetve kóros elvékonyodása figyelhető meg ( $\mathrm{D}$ és $\mathrm{H})$

GCC $=$ ganglionsejt-komplexum; OCT $=$ optikaikoherencia-tomográfia $;$ RNFL $=$ a retina idegrostrétege 
progressziójának követésében. A következőkben összefoglaljuk a legfontosabb vizsgálómódszereket, melyek segíthetnek az Alzheimer-kór korai formáinak kimutatásában.

\section{A retinalis keringés vizsgálatának lehetőségei}

\section{Fundusfotó}

A vizsgálat során egy speciális kamerával felvételt készítünk a fundusról, melyen látható az erek vastagsága, kanyargóssága, elágazódása, kereszteződési jelek. A képek digitálisan tárolhatók, és a képeken további analízisek (fraktálhányados, kaliberingadozás, kanyargósság mérése) is végezhetők (4. ábra). Ezek a paraméterek elsősorban a klinikai tünetekkel járó MCI és az Alzheimer-kór esetén mutatnak eltérést, a korai formák diagnózisában alkalmazhatóságuk csekély.
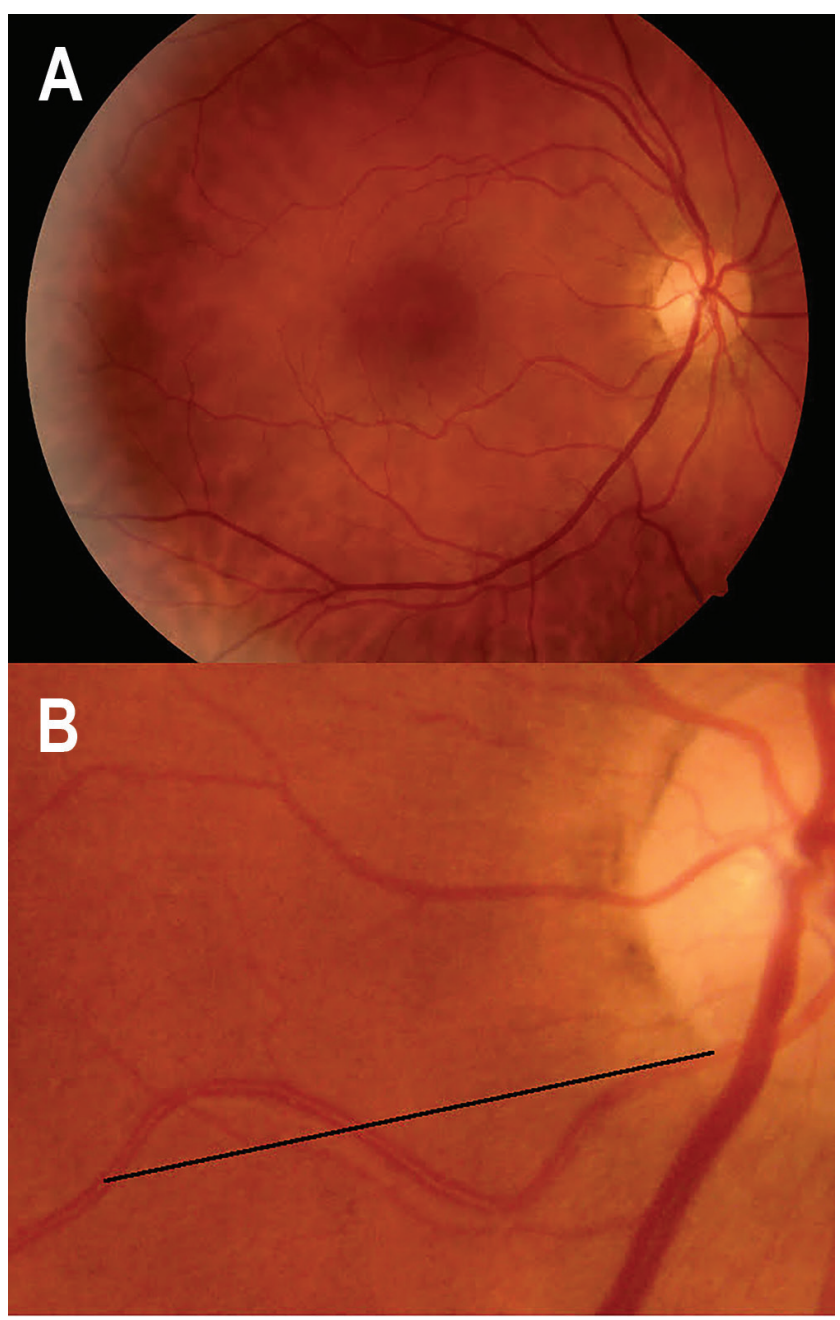

4. ábra

A: Funduskamerával készült natív színes felvétel a retináról. B Ugyanerról a felvételról kiemelve meghatározott hosszon az erek kanyargóssága meghatározható: a mért szakaszon az ér teljes hosszának és a vizsgált szakasznak a hányadosa

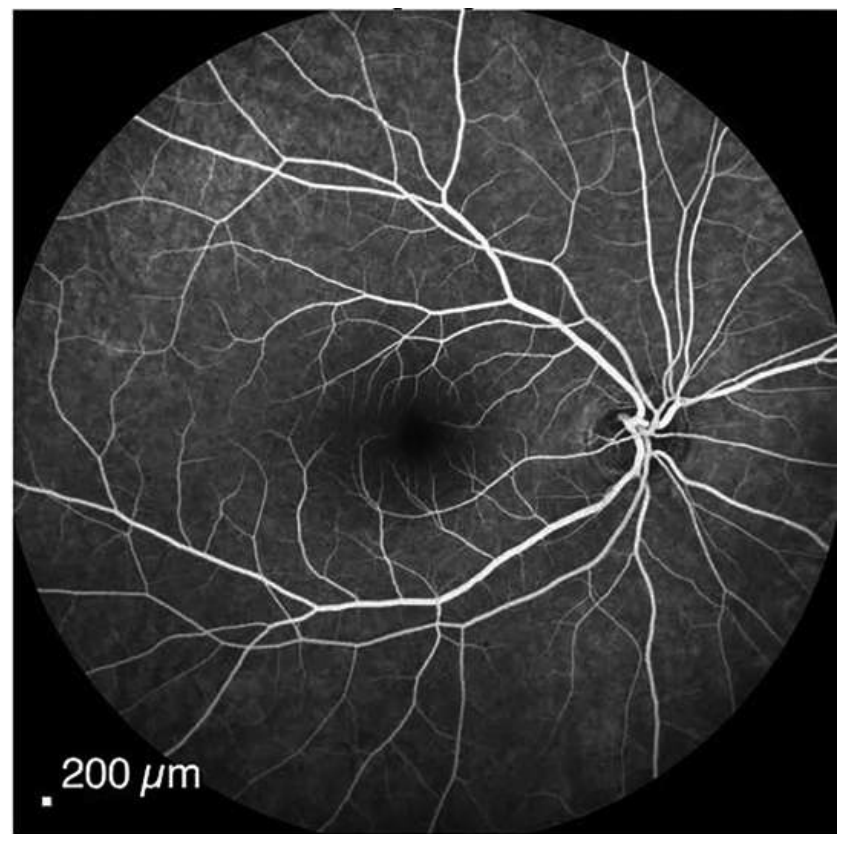

5. ábra

Egészséges retina fluoreszcens angiográfiás felvételén jó láthatók a retina erei, valamint a háttér-fluoreszcenciát adó érhártya keringése, azonban a különböző rétegek egymásra vetülése miatt a módszer kvantitatív analízisre nem alkalmas

\section{Dinamikus éranalizátor}

A dynamic vessel analyzer (DVA) módszere a retina ereinek dinamikus elemzését teszi lehetővé. A DVA müködésének elve, hogy villogó fény hatására a retina ereiben NO-mediátor keletkezik, mely értágulatot vált ki, a kaliberváltozásokat pedig a készülék folyamatos videófelvétel formájában tárolja. A retinaarteriolák fényre adott csökkent válasza az endothel-rendellenességek noninvazív értékelésében nyújt segítséget. Idős személyekben szignifikánsan kisebb az arteriolák átmérőjének növekedése villogó fény hatására, az általános endothelialis diszfunkcióval összefüggésben. A módszer ígéretes lehetőség az Alzheimer-kór és az MCI kimutatására is [33].

\section{Fluoreszcens angiográfia (FLAG)}

A fluoreszcens angiográfia az egyik legszélesebb körben alkalmazott angiográfiás módszer, amely lehetővé teszi a retina véráramlásának és az érrendszer felépítésének vizsgálatát. A fluoreszcens festéket a könyökvénába fecskendezik, majd néhány másodperc múlva az érhártya és a retina ereiben megjelenve kirajzolódnak a retina artériái, kapillárisai és vénái, továbbá jól láthatók a kóros elváltozások, mint az értágulatok, elzáródott területek, a permeabilitás fokozódása (5. ábra). A módszer hátránya, hogy invazív, illetve kvantitatív elemzésre csak korlátozottan alkalmas, így a dementiák vizsgálatában sem jutott szerephez. 


\section{Optikaikoberencia-tomográfiás angiográfia (OCTA)}

Az optikaikoherencia-tomográfián alapuló angiográfia tulajdonképpen az OCT-készülék szoftveres továbbfejlesztése a retina érhálózatának vizsgálatára. Múködésének elve, hogy gyors egymásutánban történő leképezések segítségével az azonos helyről származó keresztmetszeti képekből a mozgó vörösvértestek felismerhetők a képek kontrasztjának, amplitúdójának, intenzitásának vagy fázisának különbségeiből. A műszer számszerü adatokat nyújt a véráramlásban jelen lévő (flow area), illetve az áramlásból kiesett területek (non-flow area) nagyságáról, valamint a kapillárisok sûrüségének (vascularis denzitás) mértékéről a retina különböző rétegeiben (6. ábra). Ez a technológia számos retinabetegség diagnosztikájában és követésében használható, mint például az időskori maculadegeneráció, diabeteses retinopathia, érelzáródások, glaucoma [34, 35].

Széles körű szemészeti felhasználási területe mellett az OCTA az egyik legígéretesebb képalkotó módszer a dementiák retinalis vascularis következményeinek diagnosztikájában. 2018-ban O'Bryhim és mtsai olyan preklinikai Alzheimer-kórban szenvedőket vizsgáltak, akik a klinikai dementia jeleit egyáltalán nem mutatták (a CDRskálán 0 pont), és szemészeti megbetegedésük sem volt. A résztvevőknél PET- és liquorvizsgálatokat végeztek, ezek alapján elkülönítettek biomarker-pozitív és biomarker-negatív csoportokat. OCTA-vizsgálattal a biomarker-pozitív csoportban megfigyelték a maculában a kapillárisér-hálózatban a keringés csökkenését, ami a
FAZ megnagyobbodását okozta. Ez a jelenség a biomarker-negatív csoportban nem volt jelen, így arra a következtetésre jutottak, hogy a FAZ megnagyobbodása egy lehetséges kórjelzője az Alzheimer-kór preklinikai formájának [36].

A retinalis kapilláris keringés csökkenését MCI és Alzheimer-kór esetében számos, OCTA-vizsgálattal végzett tanulmány igazolta [37-40]. Egészséges idős személyekhez képest Alzheimer-kórban a retina felszínes és mély kapillárisplexusában szignifikánsan alacsonyabb érsürüség mérhető, mely OCTA-vizsgálaton kívül más módszerrel nem detektálható [41].

\section{Retinalis biomarkerek szerepe a vascularis dementiák korai diagnózisában}

Bár jelenleg még nem ismert a retina strukturális vagy keringési változásait számszerúsítő képalkotó módszerek szenzitivitása és specificitása, a retinalis biomarkerek vizsgálata új, ígéretes lehetőség a dementia korai formáinak kimutatására. A szemfenéki képalkotó módszerekkel lehetővé válik a retinában azon neuralis és vascularis károsodások mérése, melyek a dementiához társuló központi idegrendszeri folyamatokat reprezentálják. Ezeknek a módszereknek a PET- és a liquorvizsgálattal szemben előnyük, hogy könnyebben elérhető, gyors, noninvazív vizsgálatok, melyek segítséget nyújthatnak az Alzheimerkór preklinikai, kognitív diszfunkcióval nem társuló formáinak diagnózisában. Noha az Alzheimer-kórra jellemző strukturális és funkcionális változások a retinában a
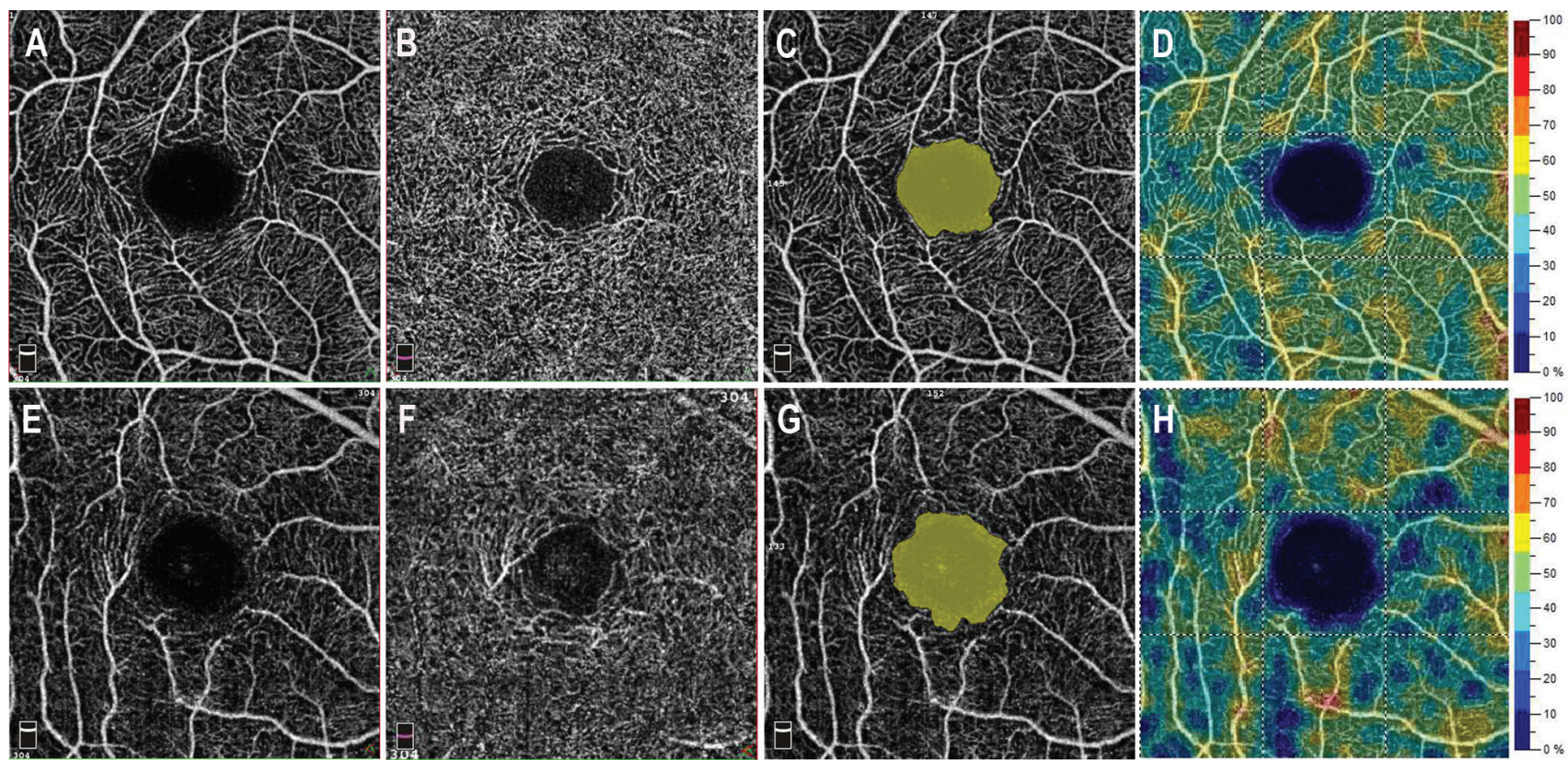

6. ábra

OCT-angiográfiás felvételek normális (A-D) és csökkent retinalis perfusio $(\mathrm{E}-\mathrm{H})$ esetén. A keringés csökkenése következtében kevesebb ér ábrázolódik mind a felszíni (A és E), mind a mély (B és F) retinalisér-hálózatban, amit a fovealis avascularis zóna megnagyobbodása is kísér (C és G). A retinalis kapillárisér-sűrűség értéke jelentősen alacsonyabb csökkent retinalis perfusio esetén (42\% vs. 52\%, D és H)

OCT $=$ optikaikoherencia-tomográfia 
normál öregedéssel kapcsolatosan is megjelenhetnek, az eddigi eredmények alapján a nem demens idős személyekkel összehasonlítva ezek már az Alzheimer-kór korai, preklinikai formáiban is súlyosabb formában jelentkeznek, így alkalmasak lehetnek a normál öregedési folyamatoktól való elkülönítésre. Feltételezhető, hogy a későbbiekben ezen paraméterek együttes, akár mesterséges intelligencia felhasználásával történő elemzésével növelhető a diagnosztikai pontosság, így elősegítve a módszer klinikai gyakorlatban való elterjedését. Jelenleg is zajlanak OCTA alkalmazásával klinikai vizsgálatok, melyekben az Alzheimer-kór kialakulására fokozott kockázatot jelentő genetikai hajlammal vagy biomarkerekkel rendelkező tünetmentes személyeket követnek. Amennyiben a fundusfotó, az OCT- és az OCTA-vizsgálat kombinációjával kellő diagnosztikai pontosság érhető el, a későbbiekben ezen vizsgálatok elvégzése javasolt minden olyan betegnél, akinél az Alzheimer-kór kialakulására vonatkozóan fokozott rizikó áll fenn, de mentális hanyatlás még nem mutatható ki. A betegség korai felismerése pedig alapvető az olyan új terápiák sikeres alkalmazásához, mint a béta-amyloid- vagy tau-fehérje-ellenes monoklonális antitestek, melyekkel a biztató kezdeti eredmények alapján megelőzhető lehet a betegség Alzheimer-kórba történő progressziója [42, 43].

Anyagi támogatás: A közlemény megírása, illetve a kapcsolódó kutatómunka az EFOP-3.6.3-VEKOP16-2017-00009. kódszámú pályázat támogatásával valósult meg.

Szerzői munkamegosztás: A vizsgálat tervezése: K. I., C. C. A vizsgálatok elvégzése: C. C., É. Á., I. L., B. F. A közlemény megírása: É. Á., K. I., C. C., B. F., I. L. A közlemény kritikai revíziója: N. Z. Zs. A cikk végleges változatát valamennyi szerző elolvasta és jóváhagyta.

Érdekeltségek: A szerzőknek nincsenek érdekeltségeik.

\section{Irodalom}

[1] Frenzel S, Wittfeld K, Habes M, et al. A biomarker for Alzheimer's disease based on patterns of regional brain atrophy. Front Psychiatry 2020; 10: 953.

[2] Alzheimer A. A peculiar disorder of the cerebral cortex. [Über eine eigenartige Erkrankung der Hirnrinde.] Allg Zeitschrift Psychiatr. 1907; 64: 146-148. [German]

[3] Penke B, Hortobágyi T, Fülöp L. Aging and the Alzheimer's disease. [Az öregedés és az Alzheimer-kór.] Magy Tud. 2016; 5: 573-583. [Hungarian]

[4] Antal M, Péter S, Eggersdorfer M. Alzheimer's disease as a worldwide public health problem. [Az Alzheimer-kór mint világméretû́ népbetegség.] Egészségtudomány 2018; 62: 58-80. [Hungarian]

[5] Lane CA, Hardy JM, Schott J. Alzheimer's disease. Eur J Neurol. 2018; 25: 59-70.

[6] Morris JC. Early-stage and preclinical Alzheimer disease. Alzheimer Dis Assoc Disord. 2005; 19: 163-165.
[7] Dubois B, Hampel H, Feldman HH, et al. Preclinical Alzhei mer's disease: definition, natural history, and diagnostic criteria. Alzheimers Dement. 2016; 12: 292-323.

[8] Sperling R, Mormino E, Johnson K. The evolution of preclinical Alzheimer's disease: implications for prevention trials. Neuron 2014; 84: 608-622.

[9] Gauthier S, Reisberg B, Zaudig M, et al. Mild cognitive impairment. Lancet 2006; 367: 1262-1270.

[10] Petersen RC, Smith GE, Waring SC, et al. Mild cognitive impairment. Clinical characterization and outcome. Arch Neurol. 1999; 56: 303-308. [Correction: Arch Neurol. 1999; 56: 760.]

[11] Rosenberg PB, Johnston D, Lyketsos CG. A clinical approach to mild cognitive impairment. Am J Psychiatry 2006; 163: 18841890

[12] Volosin M, Janacsek K, Németh D. Hungarian version of the Montreal Cognitive Assessment (MoCA) for screening mild cognitive impairment. [A Montreal Kognitiv Felmérés (MoCA) magyar nyelvú adaptálása egészséges, enyhe kognitiv zavarban és demenciában szenvedő idős személyek körében.] Psychiatr Hung. 2013; 28: 370-392. [Hungarian]

[13] Sanford AM. Mild cognitive impairment. Clin Geriatric Med. 2017; 33: 325-337.

[14] Folstein MF, Folstein SE, McHugh PR. "Mini mental state" A practical method for grading the cognitive state of patients for the clinician. J Psychiatr Res. 1975; 12: 189-198.

[15] Pákáski M, Drótos G, Janka Z, et al. Validation of the Hungarian version of Alzheimer's Disease Assessment Scale - Cognitive Subscale. [Az Alzheimer's Disease Assessment Scale kognitív alskála magyar verziójának validálása.] Orv Hetil. 2012; 153: 461466. [Hungarian]

[16] Grundman M, Petersen RC, Ferris SH, et al. Alzheimer's Disease Cooperative Study. Mild cognitive impairment can be distinguished from Alzheimer's disease and normal aging for clinical trials. Arch Neurol. 2004; 61: 59-66.

[17] Ben Jemaa S, Attia Romdhane N, Bahri-Mrabet A, et al. An Arabic version of the Cognitive Subscale of the Alzheimer's Disease Assessment Scale (ADAS-Cog): reliability, validity, and normative data. J Alzheimers Dis. 2017; 60: 11-21.

[18] Perneczky R, Wagenpfeil S, Komossa K, et al. Mapping scores onto stages: mini-mental state examination and clinical dementia rating. Am J Geriatr Psychiatry 2006; 14: 139-144.

[19] Nassreddine ZS, Phillips NA, Bédirian V, et al. The Montreal Cognitive Assessment, MoCA: a brief screening tool for mild cognitive impairmert. J Am Geriatr Soc. 2005; 53: 695-699. [Correction: J Am Geriatr Soc. 2019; 67: 1991.]

[20] Ciesielska N, Sokołowski R, Mazur E, et al. Is the Montreal Cognitive Assessment (MoCA) test better suited than the Mini-Mental State Examination (MMSE) in mild cognitive impairment (MCI) detection among people aged over 60? Meta-analysis. [Czy test Montreal Cognitive Assessment (MoCA) może być skuteczniejszy od powszechnie stosowanego Mini-Mental State Examination (MMSE) w wykrywaniu łagodnych zaburzeń funkcji poznawczych u osób po 60. roku życia? Metaanaliza.] Psychiatr Pol. 2016; 50: 1039-1052. [Polish]

[21] Hane FT, Robinson M, Lee BY, et al. Recent progress in Alzheimer's disease research. Part 3: Diagnosis and treatment. J Alzheimers Dis. 2017; 57: 645-665.

[22] Égerházi A. The early diagnosis and differential diagnosis of Alzheimer's disease with clinical methods. [Az Alzheimer-dementia korai felismerése és differenciáldiagnózisa klinikai vizsgálómódszerekkel.] Orv Hetil. 2008; 149: 2433-2440. [Hungarian]

[23] Ding Y, Sohn JH, Kawczynski MG, et al. A deep learning model to predict a diagnosis of Alzheimer disease by using ${ }^{18} \mathrm{~F}-\mathrm{FDG}$ PET of the brain. Radiology 2019; 290: 456-464.

[24] Counts SE, Ikonomovic MD, Mercado N, et al. Biomarkers for the early detection and progression of Alzheimer's disease. Neurotherapeutics 2017 ; 14: 35-53. 
[25] Hinton DR, Sadun AA, Blanks JC, et al. Optic-nerve degeneration in Alzheimer's disease. N Engl J Med. 1986; 315: 485-487.

[26] Koronyo Y, Biggs D, Barron E, et al. Retinal amyloid pathology and proof-of-concept imaging trial in Alzheimer's disease. JCI Insight 2017; 2: e93621.

[27] Csincsik L, MacGillivray TJ, Flynn E, et al. Peripheral retinal imaging biomarkers for Alzheimer's disease: a pilot study. Ophthalmic Res. 2018; 59: 182-192.

[28] Cheung CY, Chan VT, Mok VC, et al. Potential retinal biomarkers for dementia: what is new? Curr Opin Neurol. 2019; 32: 82-91.

[29] Hart NJ, Koronyo Y, Black KL, et al. Ocular indicators of Alzheimer's: exploring disease in the retina. Acta Neuropathol. 2016; 132: 767-787.

[30] Campbell J, Zhang M, Hwang T, et al. Detailed vascular anatomy of the human retina by projection-resolved optical coherence tomography angiography. Sci Rep. 2017; 7: 42201.

[31] Kwa VI, van der Sande JJ, Stam J, et al. Retinal arterial changes correlate with cerebral small-vessel disease. Neurology 2002; 59 : 1536-1540.

[32] Patton N, Aslam T, McGillivray T, et al. Retinal vascular image analysis as a potential screening tool for cerebrovascular disease: a rationale based on homology between cerebral and retinal microvasculatures. J Anatomy 2005; 206: 319-348.

[33] Lipecz A, Csipo T, Tarantini S, et al. Age-related impairment of neurovascular coupling responses: a dynamic vessel analysis (DVA)-based approach to measure decreased flicker light stimulus-induced retinal arteriolar dilation in healthy older adults. GeroScience 2019; 41: 341-349.

[34] Wylęgała A. Principles of OCTA and applications in clinical neurology. Curr Neurol Neurosci Rep. 2018; 18: 96.

[35] Resch M, Németh Cs, Barcsay Gy, et al. Angiography of the ocular fundus without dye: optical coherence tomography based an- giography in exsudative age-related macular degeneration. [Szemfenéki érfestés festék nélkül: Az optikai koherencia tomográfia alapú angiográfia exsudativ típusú időskori maculadegenerációban.] Orv Hetil. 2016; 157: 1683-1690. [Hungarian]

[36] O'Bryhim BE, Apte RS, Kung N, et al. Association of preclinical Alzheimer disease with optical coherence tomographic angiography findings. JAMA Ophthalmol. 2018; 136: 1242-1248.

[37] Bulut M, Kurtuluş F, Gözkaya O, et al. Evaluation of optical coherence tomography angiographic findings in Alzheimer's type dementia. Br J Ophthalmol. 2018; 102: 233-237.

[38] Lahme L, Esser EL, Mihailovic N, et al. Evaluation of ocular perfusion in Alzheimer's disease using optical coherence tomography angiography. J Alzheimers Dis. 2018; 66: 1745-1752.

[39] Jiang H, Wei Y, Shi Y, et al. Altered macular microvasculature in mild cognitive impairment and Alzheimer disease. J Neuroophthalmol. 2018; 38: 292-298.

[40] Querques G, Borrelli E, Sacconi R, et al. Functional and morphological changes of the retinal vessels in Alzheimer's disease and mild cognitive impairment. Sci Rep. 2019; 9: 63.

[41] Wang L, Murphy O, Caldito NG, et al. Emerging applications of optical coherence tomography angiography (OCTA) in neurological research. Eye Vis. 2018; 5: 11.

[42] Weller J, Budson A. Current understanding of Alzheimer's disease diagnosis and treatment. F1000Res. 2018; 7: 1161.

[43] Aisen P, Touchon J, Amariglio R, et al. EU/US/CTAD Task Force: lessons learned from recent and current Alzheimer's prevention trials. J Prev Alzheimers Dis. 2017; 4: 116-124.

(Kovács Illés dr., Budapest, Üllői út 26., 1085 e-mail: kovacs.illes@med.semmelweis-univ.hu)

\section{„Prima languescit senum memoria." (Seneca) (Az öregségben először az emlékezet gyengül meg.)}

A cikk a Creative Commons Attribution 4.0 International License (https://creativecommons.org/licenses/by/4.0/) feltételei szerint publikált Open Access közlemény, melynek szellemében a cikk bármilyen médiumban szabadon felhasználható, megosztható és újraközölhető, feltéve, hogy az eredeti szerző és a közlés helye, illetve a CC License linkje és az esetlegesen végrehajtott módosítások feltüntetésre kerülnek. (SID_1) 